\title{
HYDROLOGIC EFFECTS OF ANNUALLY DIVERTING 131,000 ACRE-FEET OF WATER FROM DILLON RESERVOIR, CENTRAL COLORADO
}

\section{U.S, GEOLOGICAL SURVEY}

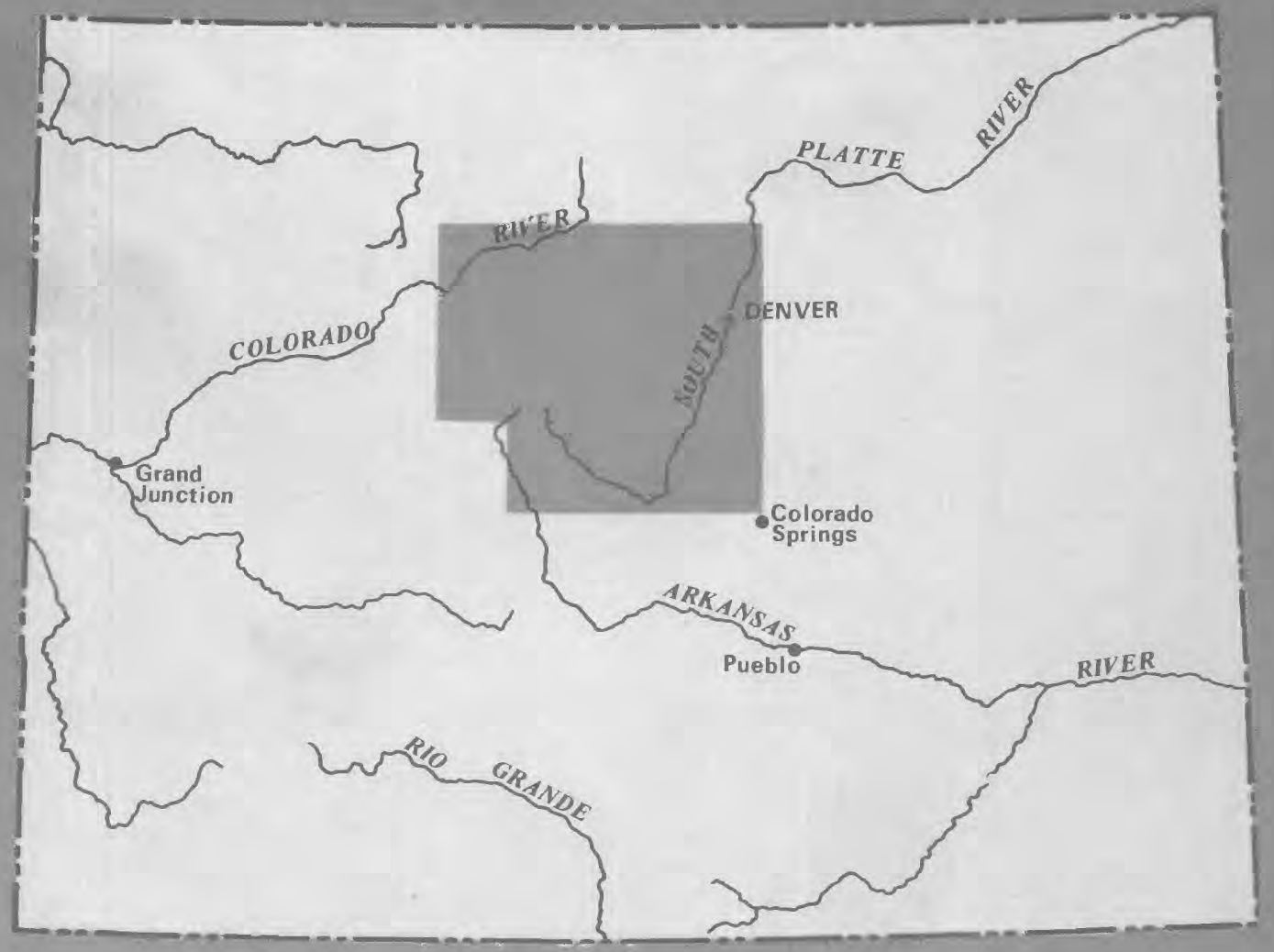

Water Resources Investigations 79-2

Prepared in cooperation with the U.S. Army Corps of Engineers 


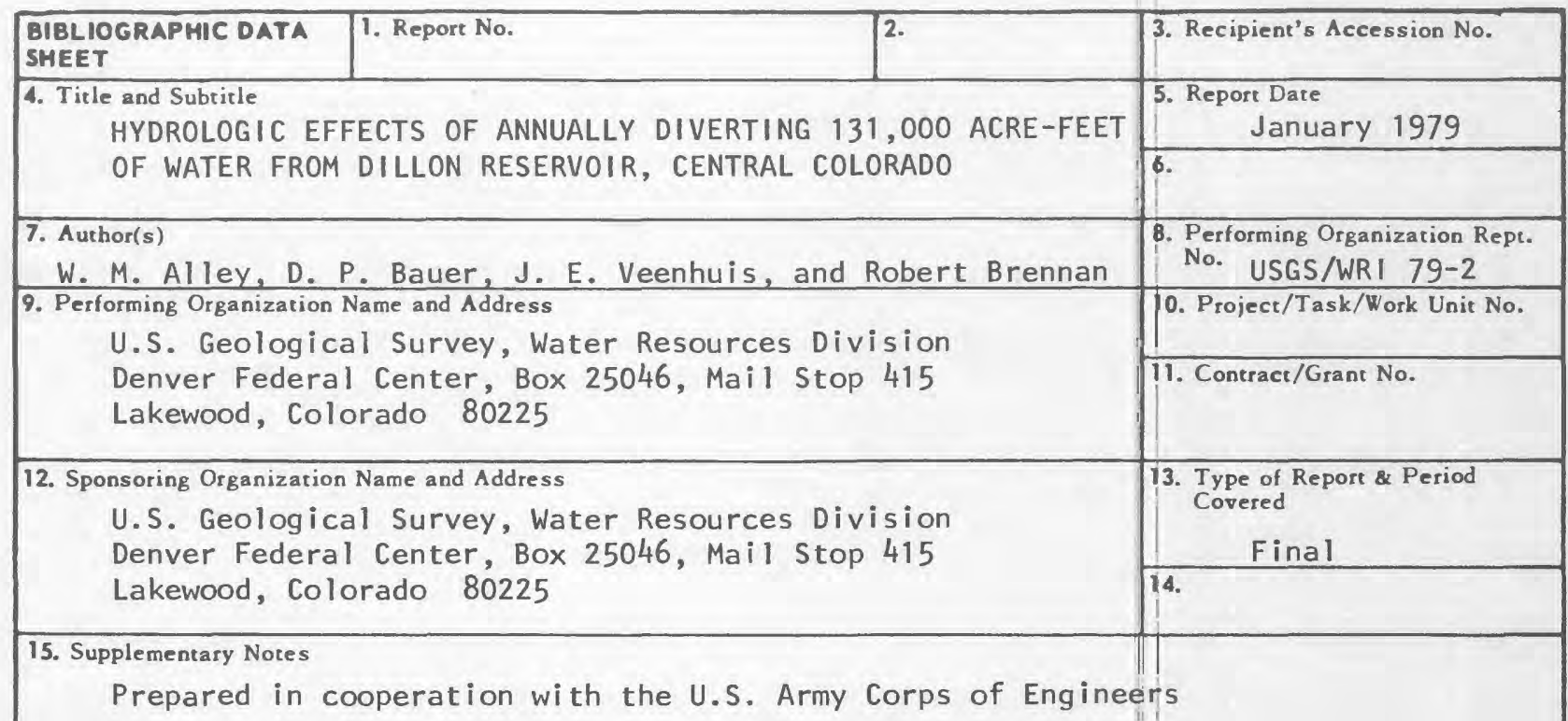

16. Abstracts Because of the increased demands for water in eastern Colorado, principally in the urbanizing Denver metropolitan area, increased diversions of water from Dillon Reservoir are planned. Estimates of end-of-month storage in Dillon Reservoir, assuming the reservoir was in place and 131,000 acre-feet of water were diverted from the reservoir each year, were reconstructed by mass balance for the 1931-77 water years. Based on the analysis, the annual maximum end-of-month drawdown below the elevation at full storage would have averaged 54 feet. The maximum end-of-month drawdown below the elevation at full storage would have been 171 feet.

The mean-annual discharge-weighted dissolved-solids concentrations in the Colorado River near Glenwood Springs and Cameo, Colo., and Cisco, Utah, for the 1942-77 water years, were computed assuming an annual diversion of 131,000 acre-feet of water from Dillon Reservoir. The average increases in the dissolved-solids concentrations with the 131,000-acre-foot diversion were 15 to $16 \mathrm{milligrams}$ per $l i$ ter at the three sites.

17. Key Words and Document Analysis. 170. Descriptors

Colorado, Surface-water availability, Water resources, Water storage, Water supply

17b. Identifiers/Open-Ended Terms

Colorado River basin, Dillon Reservoir, Dissolved solids, Reservoir analysis, Summit County

17c. $\cos A$ TI Field/Group

18. Availability Statement

No restriction on distribution

\begin{tabular}{|l|c|}
$\begin{array}{l}\text { 19. Security Class (This } \\
\text { Report) } \\
\text { UNCLASSUELED }\end{array}$ & $\begin{array}{c}\text { 21. No. of Pages } \\
22\end{array}$ \\
\begin{tabular}{|c|} 
20. Security Class (This \\
Page \\
UNCLASSIFIED
\end{tabular} & 22. Price \\
\hline
\end{tabular}


HYDROLOGIC EFFECTS OF ANNUALLY DIVERTING

131,000 ACRE-FEET OF WATER FROM DILLON RESERVOIR,

CENTRAL COLORADO

By William M. Alley, Daniel P. Bauer, Jack E. Veenhuis, and Robert Brennan

U.S. GEOLOGICAL SURVEY

Water-Resources Investigations 79-2

Prepared in cooperation with the

U.S. Army Corps of Engineers 


\section{UNITED STATES DEPARTMENT OF THE INTERIOR}

CECIL D. ANDRUS, Secretary

GEOLOGICAL SURVEY

H. William Menard, Director

For additional information write to:

District Chief

U.S. Geological Survey

Box 25046, Mail Stop 415

Denver Federal Center

Lakewood, CO 80225 
Metric conversions. . . . . . . . . . . . . . . . . . . . .

Abstract.

Introduction.

Description of study area

Surface-water rights.

Monthly mass-balance analysis of reservoir storage. . . . . .

Approach ............................

Period of analysis... . . . . . . . . . . . . . . . .

Data requirements. . . . . . . . . . . . . . . . . . . .

Monthly inflows . . . . . . . . . . . . . . . . . . .

Monthly diversions.

Monthly net evaporation . . . . . . . . . . . . . . .

Monthly downstream releases . . . . . . . . . . . . . .

Results of mass-balance analysis. . . . . . . . . . . . . . . . . . . . .

Dissolved-solids concentrations in the Colorado.River . . . . . . . .

Summary . . . . . . . . . . . . . . . . . . . . . . . . . . .

References.

\section{ILLUSTRATIONS}

Figure 1. Map showing location of study area . . . . . . . . . .

2-6. Graphs showing:

2. Relationship of surface area and storage to elevation of Dillon Reservoir. . . . . . . . . . . . .

3. Annual "natural" streamflow of the Blue River at Dillon and cumulative departure from the average (1912-77 water years)... . . . . . . . . . .

4. Maximum and minimum end-of-month storage, surface area, and elevation in Dillon Reservoir during each water year (1931-77 water years).

5. Percentage of time that indicated end-of-month elevations of Dillon Reservoir were equaled or exceeded (1931-77 water years) . . . . . . . .

6. Dissolved-solids concentrations (mean-annual discharge-weighted) at selected sites on the Colorado River (1942-77 water years) . . . . . . . 


\section{TABLES}

Table 1. Description of streamflow-gaging stations. . . . . . . .

2. Proposed monthly diversion schedule for Harold D. Roberts Tunnel used in mass-balance analysis . . . . . . . 10

3. Minimum end-of-month reservoir elevation, surface area, and storage (1931-77 water years). . . . . . . . . 14

4. Recommended guidelines for dissolved solids in irrigation water. .................

METRIC CONVERSIONS

Multiply inch-pound unit

inch

foot $(f t)$

mile $(\mathrm{mi})$

acre

square mile $\left(m i^{2}\right)$

mile per hour

acre-foot (acre-ft)

cubic foot per second $\left(\mathrm{ft}^{3} / \mathrm{s}\right)$

millibar
By

25.40

2.54

0.3048

1.609

0.4047

2.590

1.609

0.001233

0.02832

100.0
To obtain metric unit

millimeter

centimeter

meter

kilometer

hectare

square kilometer

kilometer per hour

cubic hectometer

cubic meter per second newton per square meter 


\section{HYDROLOGIC EFFECTS OF ANNUALLY DIVERTING 131,000 ACRE-FEET}

OF WATER FROM DILLON RESERVOIR, CENTRAL COLORADO

By William M. Alley, Daniel P. Bauer, Jack E. Veenhuis, and Robert Brennan

\section{ABSTRACT}

Because of the increased demands for water in eastern Colorado, principally in the urbanizing Denver metropolitan area, increased diversions of water from Dillon Reservoir are planned. The U.S. Army Corps of Engineers requested the U.S. Geological Survey to determine the hydrologic effects of annually diverting 131,000 acre-feet of water from Dillon Reservoir.

Estimates of end-of-month storage in Dillon Reservoir, assuming the reservoir was in place and 131,000 acre-feet of water were diverted from the reservoir each year, were reconstructed by mass balance for the 1931-77 water years. Based on the analysis, the annual maximum end-of-month drawdown below the elevation at full storage would have averaged 54 feet. The maximum endof-month drawdown below the elevation at full storage would have been 171 feet.

The mean-annual discharge-weighted dissolved-solids concentrations in the Colorado River near Glenwood Springs and Cameo, Colo., and Cisco, Utah, for the 1942-77 water years, were computed assuming an annual diversion of 131,000 acre-feet of water from Dillon Reservoir. The average increases in the dissolved-solids concentrations with the 131,000-acre-foot diversion were 15 to 16 milligrams per liter at the three sites.

\section{INTRODUCTION}

Because of the increased demands for water in eastern Colorado, principally in the urbanizing Denver metropolitan area, increased diversions of water from Dillon Reservoir are planned (U.S. Department of the Interior, 1977). The U.S. Army Corps of Engineers, who are involved with the implementation of these diversions, requested the U.S. Geological Survey to determine the hydrologic effects of annually diverting 131,000 acre-ft of water from Dillon Reservoir. 
On the basis of the planned increases in transmountain diversions from Dillon Reservoir, the purposes of this study were to determine the effects of the diversions on the storage in Dillon Reservoir and to determine the effects of the diversions on the dissolved-solids concentrations in the Colorado River near Glenwood Springs and Cameo, Colo, and Cisco, Utah. The effects on storage were to be determined on a monthly basis, and the effects on dissolved-solids concentrations were to be determined on a yearly basis.

\section{DESCRIPTION OF STUDY AREA}

Dillon Reservoir is located in the Blue River basin west of the Continental Divide, approximately $70 \mathrm{mi}$ west of Denver, Colo. (fig. 1). The spillway elevation of the dam is $9,017 \mathrm{ft}$ and the reservoir has an active storage ${ }^{l}$ capacity of 254,036 acre-ft with a full-capacity surface area of 3,233 acres and maximum depth of $188 \mathrm{ft}$. The relationship of surface area and storage to elevation of Dillon Reservoir is shown in figure 2. The dam was completed in 1963 and the reservoir filled during 1964 and 1965 . Major tributaries to the reservoir are the Blue and Snake Rivers and Tenmile Creek. The drainage area upstream from the dam is $335 \mathrm{mi}^{2}$. Water is diverted from Dillon Reservoir to the North Fork South Platte River by way of the Harold D. Roberts Tunnel.

Upstream from Dillon Reservoir, water is diverted from the Blue River basin through the Hoosier Pass Tunnel and the Boreas Pass ditch to the South Platte River basin (fig. 1). Water has been diverted through the Hoosier Pass Tunnel since June 1952. Annual diversions have averaged 7,900 acre-ft. Water has been diverted through the Boreas Pass ditch since 1909. Annual diversions have averaged 100 acre-ft. Water was diverted from Tenmile Creek through the Fremont Pass ditch to the Arkansas River basin from 1929 to 1943. Annual diversions averaged 1,230 acre-ft. Water for power generation, which averaged 17,000 acre-ft per year, was diverted from the Snake River prior to December 15, 1959. The water was returned to the Blue River downstream from Dillon Reservoir.

Green Mountain Reservoir is located approximately $21 \mathrm{mi}$ downstream from Dillon Reservoir. Water stored in Green Mountain Reservoir is used for irrigation and for power generation. Water from Green Mountain Reservoir flows into the Colorado River about $15 \mathrm{mi}$ downstream from the dam.

\section{SURFACE-WATER RIGHTS}

Surface water in the Blue River basin is presently (1978) being used by a variety of users both within and outside of the basin. As noted by Knudsen and Danielson (1977), Colorado uses the doctrine of Prior Appropriation or

${ }^{1}$ Active storage is storage above the elevation of the bottom or invert of the reservoir outlet to the Blue River $(8,829 \mathrm{ft})$. The term "storage" as used in this report will refer to active storage. 


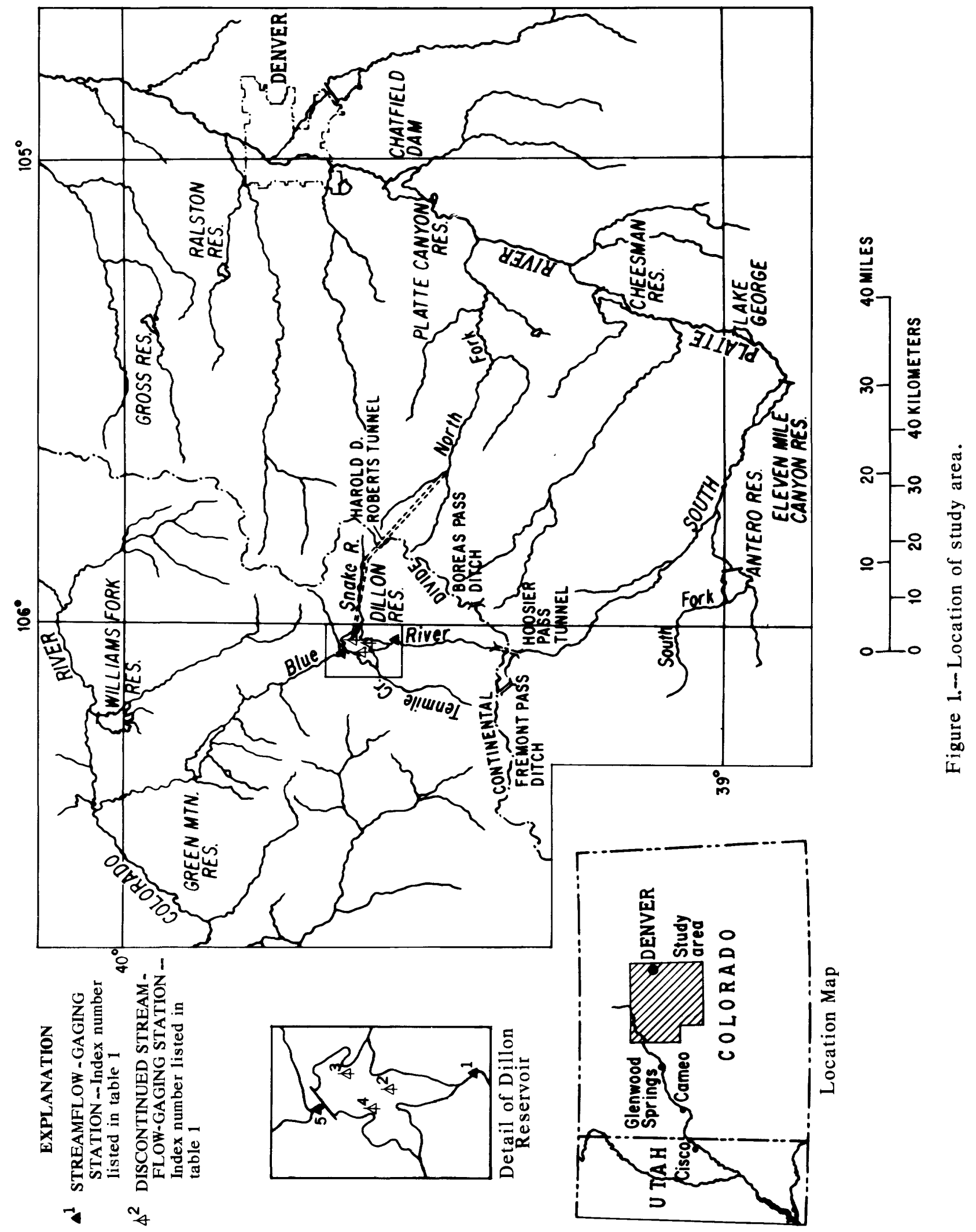




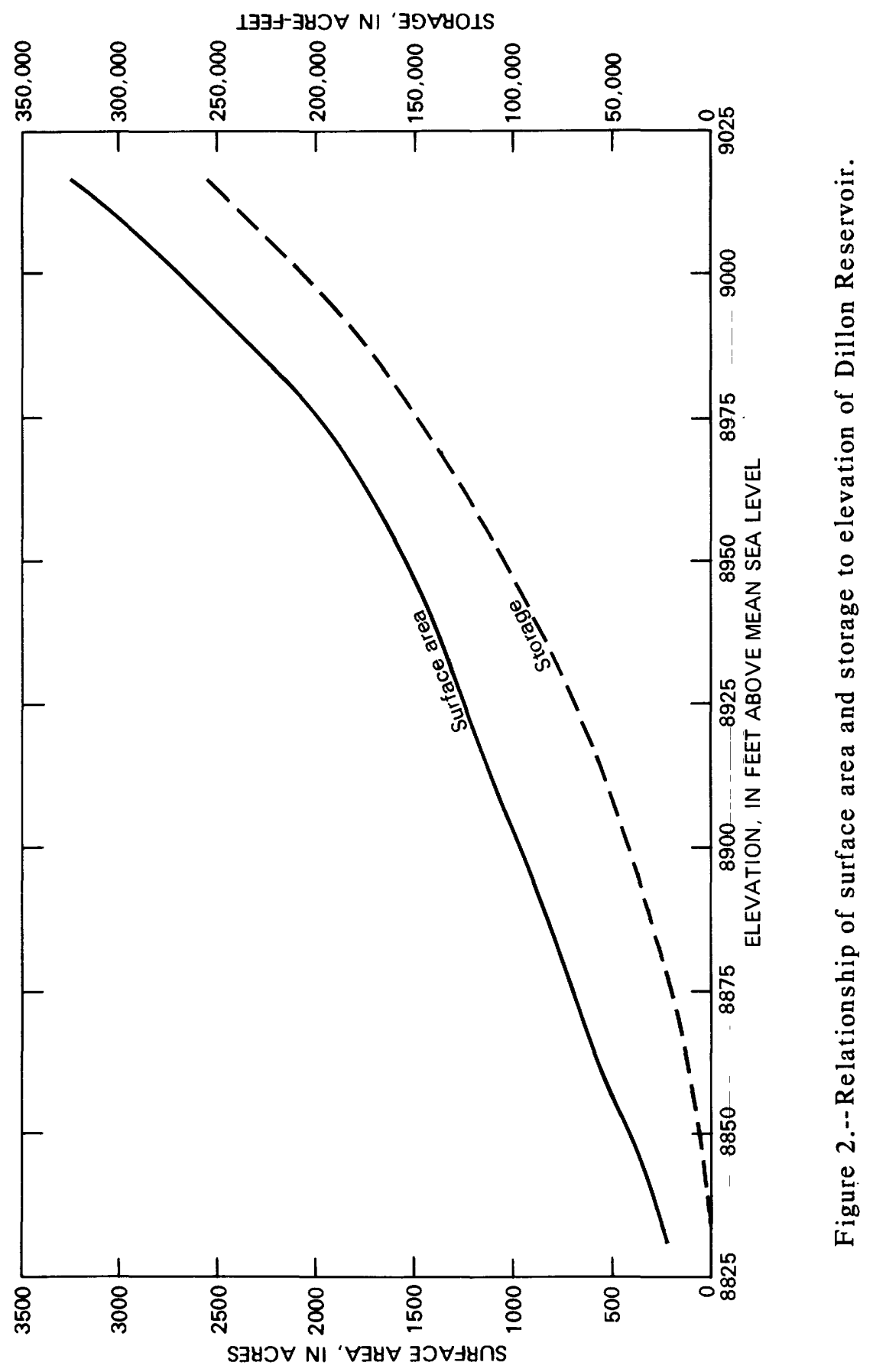


"first in time, first in right" in determining and administrating surfacewater rights.

As long as there is sufficient water available to meet all demands there are few problems. But, as noted by Knudsen and Danielson (1977), "If there is insufficient water to meet all demands, then the priority date would be used to allocate the available water as follows: those priorities most recent in time (that is, junior priorities) must allow sufficient surface water to pass by their points of diversion in order to let downstream priorities earlier in time (that is, senior priorities) receive the water due them according to their decree as adjudicated by the judicial system."

Surface-water rights decreed to diversions through the Hoosier Pass Tunnel and to power generation and storage in Green Mountain Reservoir are senior to water rights decreed to diversions through the Harold D. Roberts Tunnel. These surface-water rights were considered in the monthly massbalance analysis. Several relatively small diversions within the basin and diversions through the Boreas Pass ditch were not considered in the analysis.

\section{MONTHLY MASS-BALANCE ANALYSIS OF RESERVOIR STORAGE}

\section{Approach}

Hypothetical monthly mass balances of storage in Dillon Reservoir, assuming an annual diversion of 131,000 acre-ft of water, were reconstructed for water years ${ }^{2}$ 1931-77 using available data. The reconstructed data may be used to predict future effects of an annual diversion of 131,000 acre-ft of water on storage in and outflow from Dillon Reservoir, assuming that future hydrologic conditions will be similar to the historic hydrologic conditions on which the analysis is based. The mass-balance analysis was based on the principle of continuity as expressed by the equation:

$$
S_{i}=S_{i-1}+I_{i}-D_{i}-E_{i}-O_{i}
$$

where:

$S_{i}=$ reservoir storage at the end of the current month, $i$, in acre-feet;

$S_{i-1}=$ reservoir storage at the end of the previous month, $i-1$, in acre-feet;

$I_{i}=$ inflow to the reservoir during month $i$, in acre-feet;

$D_{i}=$ transmountain diversion from the reservoir during month $i$, in acre-

$E_{i}=$ net evaporation from the reservoir during month $i$, in acre-feet; and $o_{i}=$ downstream releases from the reservoir during month $i$, in acre-feet.

${ }^{2} \mathrm{~A}$ water year begins on October 1 , ends on September 30 , and is designated by the calendar year in which it ends. 
The availability of streamflow data in the vicinity of Dillon Reservoir was the governing factor in selecting a period of analysis. Streamflow data used in this study were based on streamflow records collected by the U.S. Geological Survey. Descriptions of the streamflow-gaging stations are shown in table 1, and the stations are located on figure 1.

The longest period for which adequate streamflow records were available to define monthly inflow to Dillon Reservoir was for the 1930-77 water years. Streamflow during this period was compared to streamflow during the 1912-77 water years using the "natural" streamflow at station 2 (Blue River at Dillon) (fig. 1 and table 1 ).

"Natural" streamflow at station 2 was determined as follows: Monthly interstation flow coefficients between stations 1 (Blue River near Dillon) and 2 (Blue River at Dillon) were derived using the October 1957-April 1961 records from both stations. The streamflow record for station 2 was then extended through water year 1977 using the monthly interstation flow coefficients and monthly streamflow at station 1. To establish a "natural" streamflow record for station 2, the transmountain diversions through the Hoosier Pass Tunnel, which began in 1952, were then added to the streamflow at station 2 .

The resulting annual "natural" streamflow and cumulative departure from the average annual "natural" streamflow at station 2 are shown in figure 3. During periods of above-average streamflow, the cumulative departure from the average will increase while, during periods of below-average streamflow, the cumulative departure from the average will decrease. The data in figure 3 indicate that inflow to Dillon Reservoir generally would have been above average during water years 1912-30 and of ten would have been below average thereafter. If Dillon Reservoir had been in place from water years 1912-77 and 131,000 acre-ft of water had been diverted each year, then reservoir storage probably would have been lowest during the periods of steepest decline of the curve showing the cumulative departure from the average (fig. 3). Thus, the period when reservoir storage would have been lowest was apparently after the 1930 water year and probably would have occurred during the mid-1950's or late 1960's. During the 1925-30 water years, the Blue River annual flowrates near the Dillon Reservoir's present location were above average (see fig. 3). For this reason, the analysis was begun with the 1931 water year assuming the reservoir was in place and full at this time.

\section{Data Requirements}

Solving the mass-balance equation (equation 1) required the following data: Monthly inflows to the reservoir, monthly diversions from the reservoir, monthly net evaporation from the reservoir, and monthly downstream releases from the reservoir. 


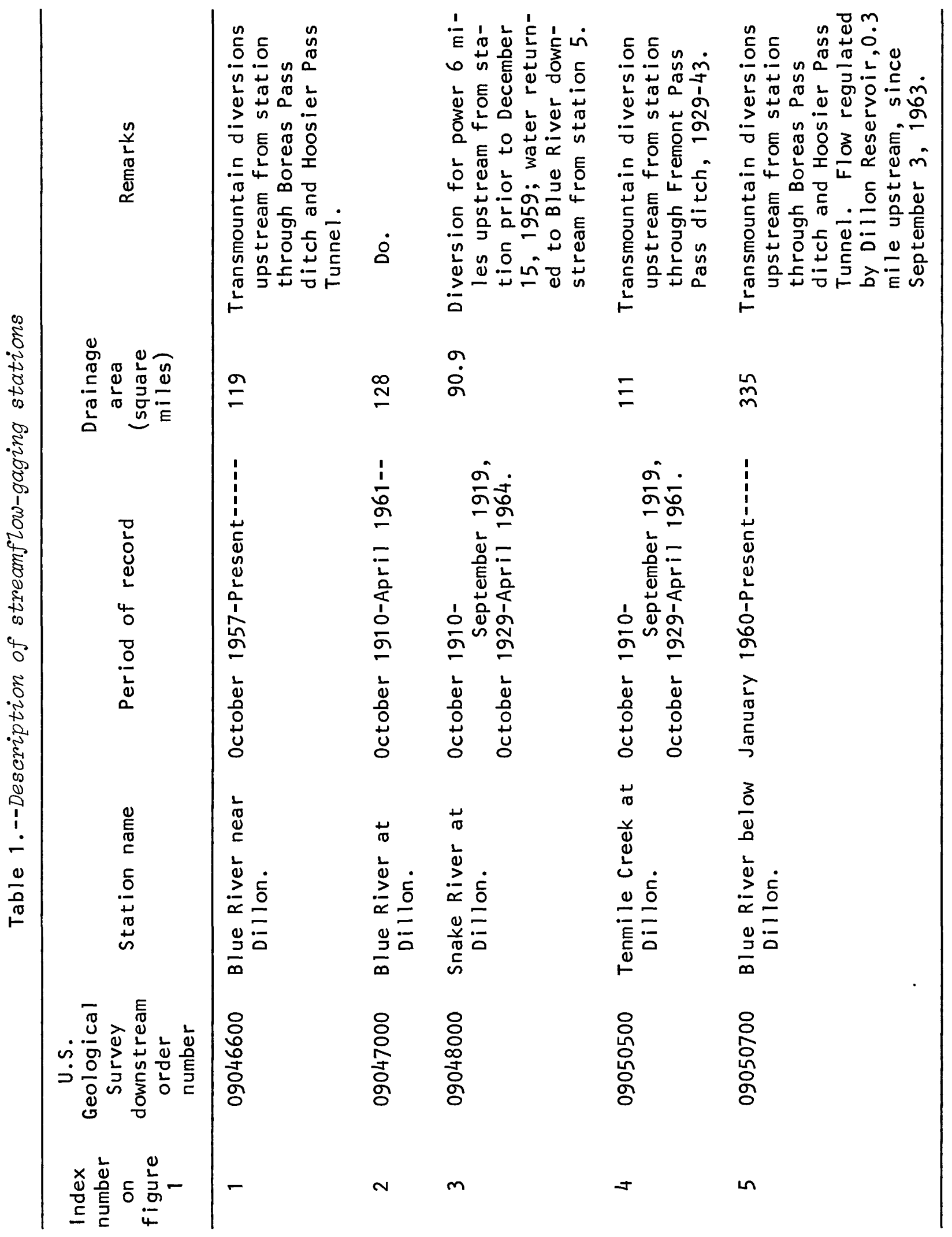




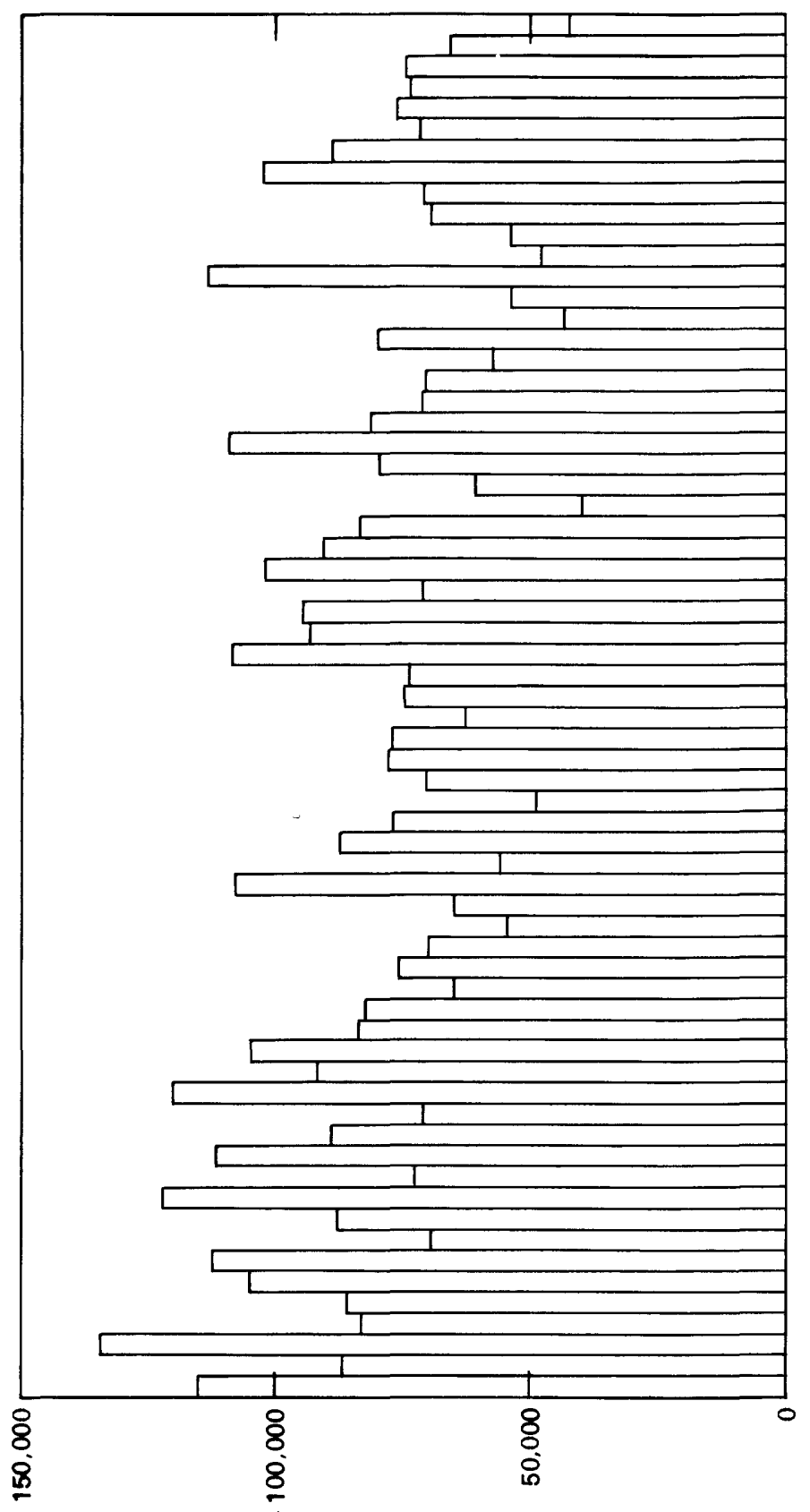

$1 \exists \exists \exists-\exists \forall O \forall N N^{\prime} M O 7-\exists W \forall \exists \forall 1 S$, $7 \forall \forall \cap \perp \forall N$, , $7 \forall \cap N N \forall$

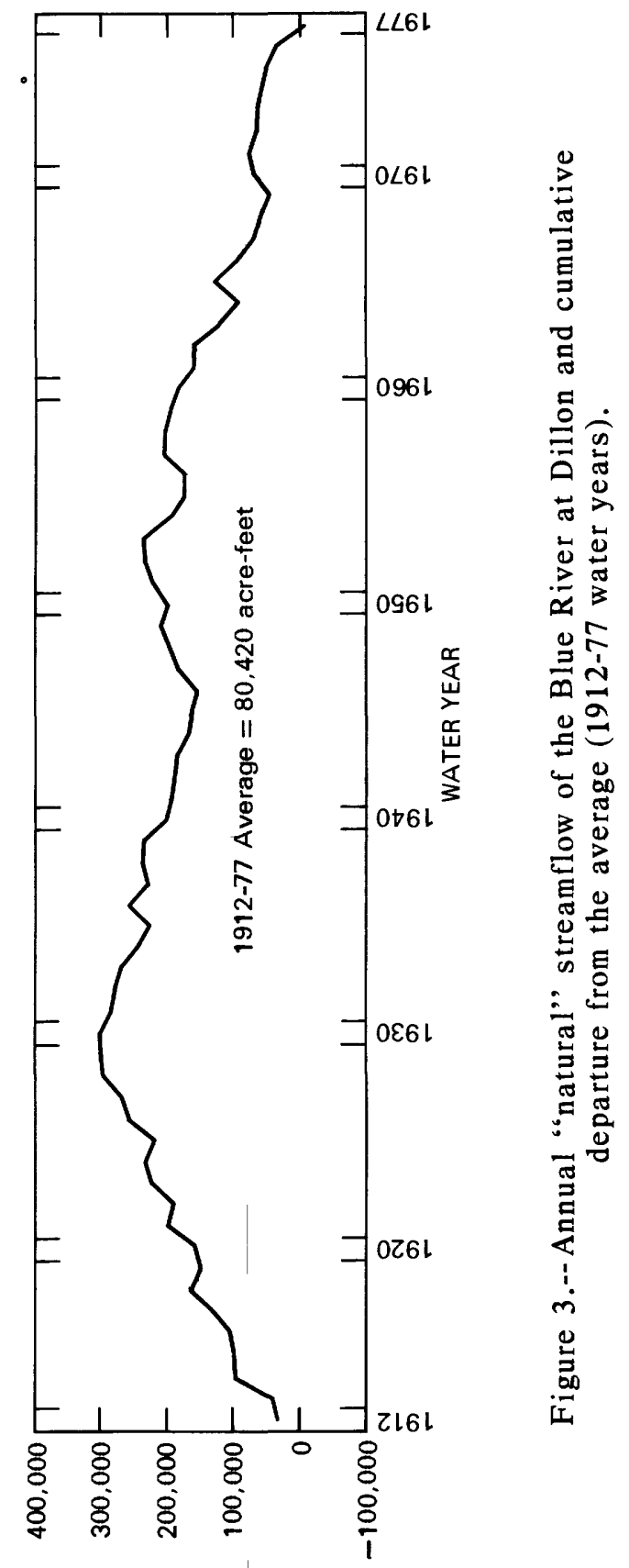

$1 \exists \exists y-\exists \forall ว \forall N 1$ ' $\exists \supset \forall \forall \exists \wedge \forall \exists H \perp$

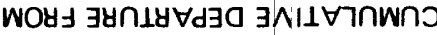


Monthly inflows to Dillon Reservoir from October 1930 through December 1959 were determined by first adding the monthly flows at stations 2, 3, and 4 (fig. 1 and table 1). Then, the average monthly diversions through Hoosier Pass Tunnel during the 1952-77 water years were subtracted from the accumulated monthly flows prior to the 1952 water year. Finally, monthly diversions through Fremont Pass ditch and monthly diversions from the Snake River for power generation were added to the accumulated monthly flows. Streamflow records for station 5 were used to determine monthly inflows from January 1960 through August 1963. Monthly diversions through Harold D. Roberts Tunnel, monthly downstream releases, and monthly changes in storage were known for the actual reservoir operation between september 1963 and September 1977. These data along with estimates of monthly net evaporation, as developed in a following section, were used to calculate monthly inflows to Dillon Reservoir during this period using the following equation:

$$
I_{i}=D_{i}+E_{i}+O_{i}+\left(S_{i}-S_{i-1}\right) \text {, }
$$

where all variables are as defined in equation 1.

\section{Monthly Diversions}

An annual diversion of 131,000 acre- $f t$ was used according to the proposed monthly diversion schedule for the Harold D. Roberts Tunnel in 1988. These data, which were obtained from the U.S. Bureau of Reclamation (J.D. Hall, written commun., 1978), are shown in table 2.

The bottom or invert of the Harold D. Roberts Tunnel at Dillon Reservoir is at an elevation of $8,846 \mathrm{ft}$. If the end-of-month reservoir elevation using equation 1 was less than $8,846 \mathrm{ft}$, the diversion for that month was decreased in the analysis until the end-of-month reservoir elevation was at $8,846 \mathrm{ft}$.

\section{Monthly Net Evaporation}

Net evaporation is evaporation minus precipitation on the reservoir surface. Monthly net evaporation from Dillon Reservoir was computed using the following equation:

$$
E_{i}=\left(E V_{i}-P_{i}\right) \cdot \bar{A}_{i} / 12 \text {, }
$$

where:

$E_{i}=$ net evaporation from the reservoir during month $i$, in acre-feet;

$E V_{i}=$ evaporation during month $i$, in inches;

$P_{i}=$ precipitation during month $i$, in inches; and

$\bar{A}_{i}=$ average reservoir surface area during month $i$, in acres. 
Table 2.--Proposed monthly diversion schedule for Harold D. Roberts Tunnel used in mass-balance analysis

[J. D. Hall, written commun., 1978]

\begin{tabular}{|c|c|}
\hline Month & Diversion, in acre-feet \\
\hline $\begin{array}{l}\text { October } \\
\text { November } \\
\text { December } \\
\text { January }\end{array}$ & $\begin{array}{l}13,800 \\
10,200 \\
10,200 \\
10,100\end{array}$ \\
\hline $\begin{array}{l}\text { February } \\
\text { March- } \\
\text { Apri } 1-20 \\
\text { May- }\end{array}$ & $\begin{array}{r}8,800 \\
9,600 \\
12,100 \\
12,100\end{array}$ \\
\hline $\begin{array}{l}\text { June } \\
\text { July } \\
\text { August } \\
\text { September }\end{array}$ & $\begin{array}{r}3,900 \\
9,400 \\
17,100 \\
13,700\end{array}$ \\
\hline Total & 131,000 \\
\hline
\end{tabular}

Monthly evaporation ( $E V$ in equation 3) for 1969-71 was measured during energy-budget studies conducted by Ficke, Adams, and Danielson (1977). Monthly evaporation for 1971-77 was computed using a mass-transfer equation derived by Harbeck (1962):

$$
E V_{i}=N \cdot u \cdot\left(e_{0}-e_{a}\right) / 2.54
$$

where:

$N=$ an empirical coefficient;

$u=a v e r a g e$ wind speed at 2 meters above water surface, in miles per hour;

$e_{0}=$ saturation vapor pressure of air at temperature of the water surface, in millibars;

$e_{\alpha}=$ vapor pressure of the air, in millibars; and

$2.54=$ conversion factor (centimeters per inch).

On the basis of the energy-budget studies of 1969-71, the $N$ coefficient for Dillon Reservoir was estimated to be 0.00796 (Ficke and others, 1977). This value, along with wind-speed and vapor-pressure data, was used in equation 4 to compute monthly evaporation for 1971-77. Prior to 1969, monthly evaporation rates were assumed to be the average monthly values obtained for 1969-77. 
Monthly precipitation data ( $P_{i}$ in equation 3$)$ for the entire period of analysis (1931-77 water years) were obtained from the U.S. Environmental Data Service (1966-72) and the U.S. Weather Bureau (1930 and 1961-66; 1954; 1964).

\section{Monthly Downstream Releases}

Stipulations for the operation of Dillon Reservoir require release of inflow to the reservoir or $50 \mathrm{ft}^{3} / \mathrm{s}$, whichever is less, or "small" flows in times of water shortage (U.S. Department of the Interior, 1977). Therefore, the minimum allowable downstream release from Dillon Reservoir during a month was set at the inflow for the month or $50 \mathrm{ft}^{3} / \mathrm{s}$, whichever was less. During high flow months (June to August) occasional uncontrolled releases (spills) occur as a result of a maximum reservoir storage of 254,036 acre-ft. Many times, during August and September, release of additional water from Dillon Reservoir was required to meet the decreed water rights for Green Mountain Reservoir.

The additional releases required to meet the decreed water rights for Green Mountain Reservoir were determined as follows. During the mass-balance analysis, the sum of the spills from Dillon Reservoir for the water year plus the local inflow between Dillon and Green Mountain Reservoirs during May, June, and July was computed. Local inflows between Dillon and Green Mountain Reservoirs were computed by subtracting the historic streamflows of the Blue River at station 5 or the sum of the historic streamflows at stations 2, 3 , and 4 (U.S. Geological Survey, 1954, 1964, 1961-74, 1975-76, 1977) from the historic inflows to Green Mountain Reservoir (J. D. Hall, written commun., 1978).

The U.S. Bureau of Reclamation estimated that the sum of spills plus local inflow during May, June, and July should equal at least 110,000 acre-ft in order to meet water requirements for Green Mountain Reservoir (J. D. Hall, written commun., 1978). Any deficit was reduced by additional releases from Dillon Reservoir, so long as these releases did not exceed the total 12month inflow to Dillon Reservoir during the preceding year. These additional releases began in August in increments of as much as 25,000 acre-ft per month until the deficit was eliminated.

\section{RESULTS OF MASS-BALANCE ANALYSIS}

The maximum and minimum end-of-month reservoir storage, surface area, and elevation that would have occurred during each water year are shown in figure 4. The data indicate considerable fluctuation in reservoir storage would have occurred during the period analyzed. The average annual minimum and the minimum end-of-month reservoir elevation, surface area, and storage are listed in table 3.

The percentage of time that indicated end-of-month elevations of Dillon Reservoir would have been equaled or exceeded is shown in figure 5 . For 

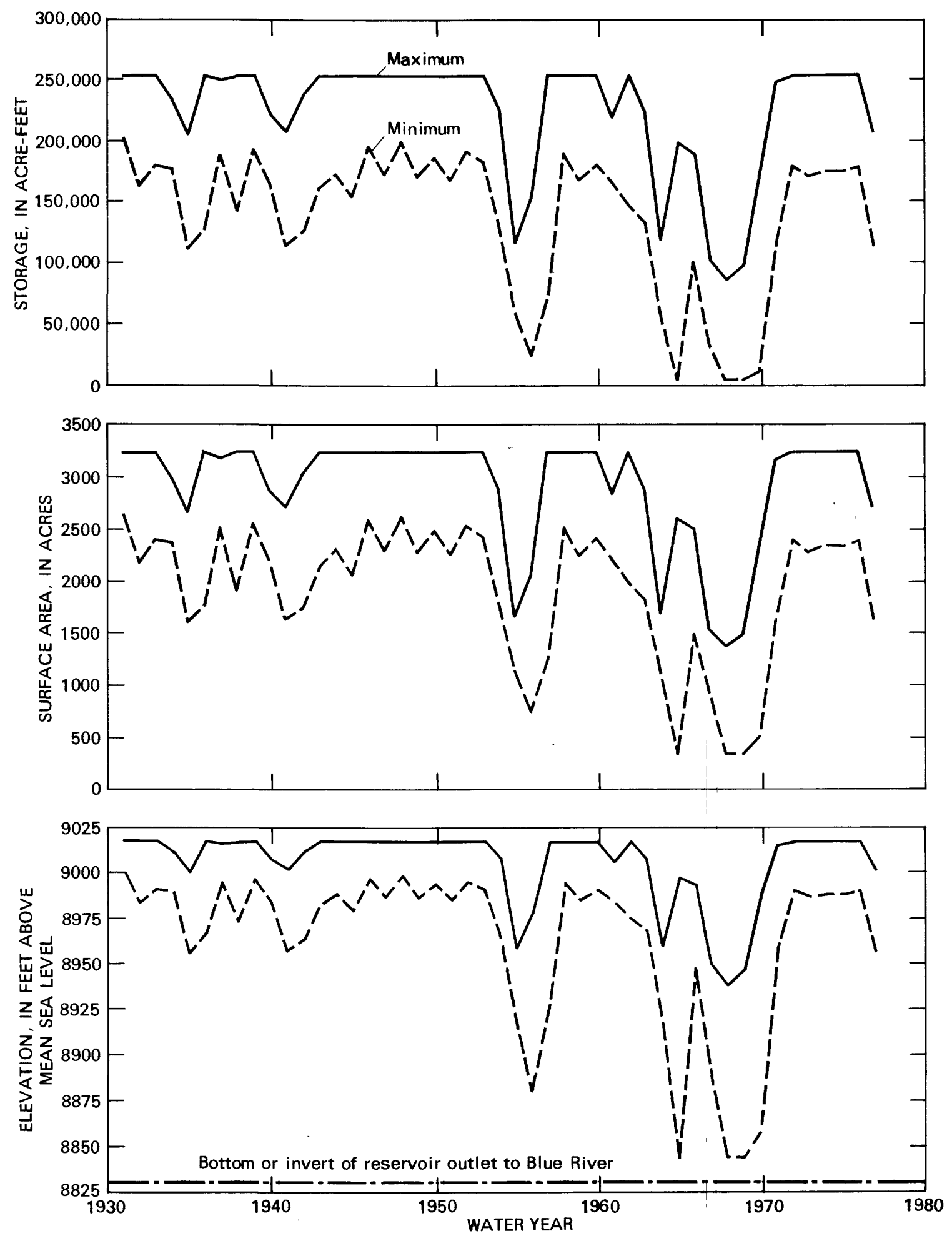

Figure 4.--Maximum and minimum end-of-month storage, surface area, and elevation in Dillon Reservoir during each water year (1931-77 water years). 


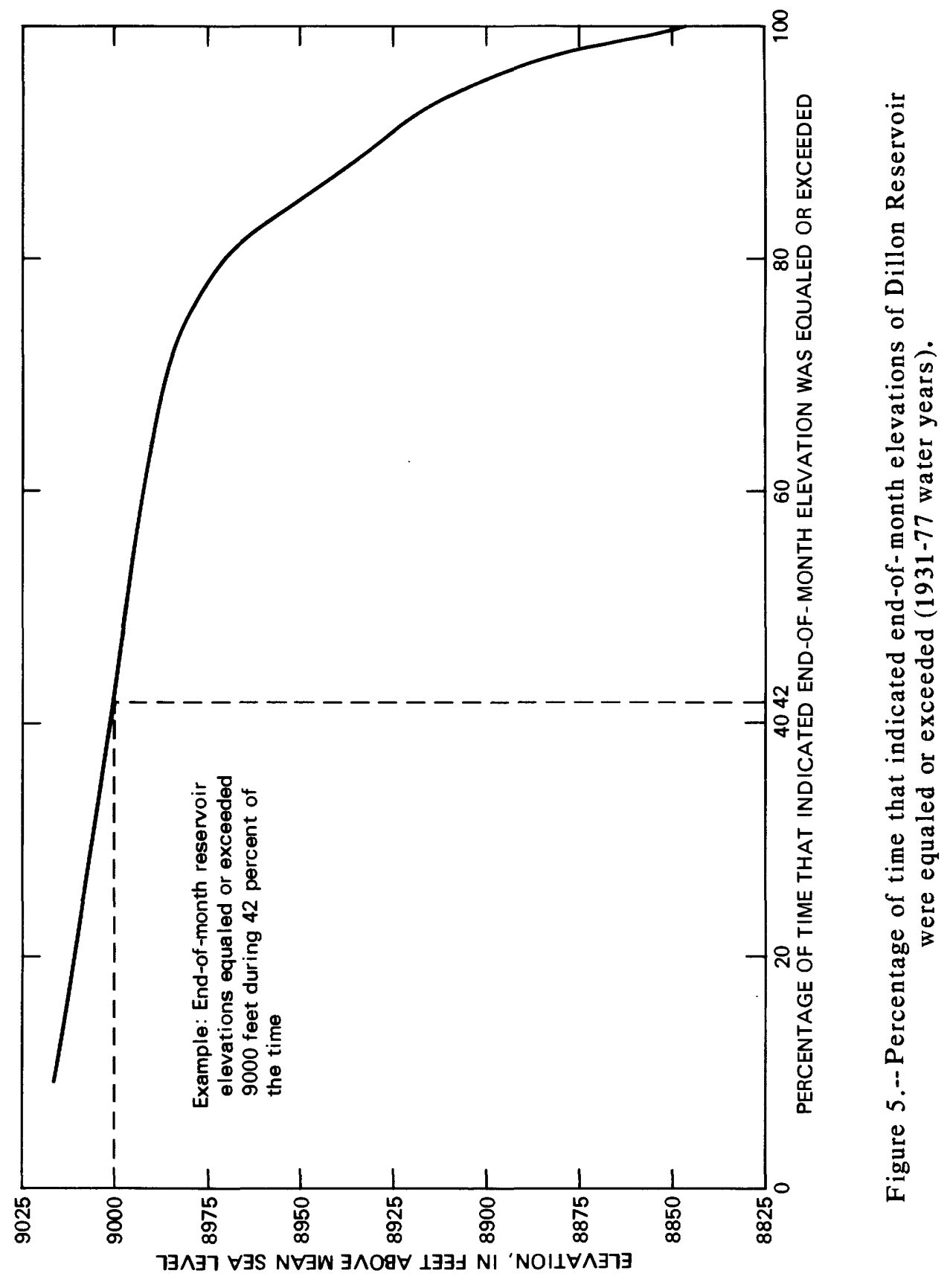


example, figure 5 indicates that 42 percent of the time the end-of-month elevation of Dillon Reservoir would have equaled or exceeded 9,000 $\mathrm{ft}$.

Table 3.--Minimum end-of-month resemoir elevation, surface area, and storage (1931-77 water years)

\begin{tabular}{lccr}
\hline Characteristic & $\begin{array}{c}\text { End-of-month } \\
\text { reservoir } \\
\text { elevation, } \\
\text { in feet }\end{array}$ & $\begin{array}{c}\text { End-of-month } \\
\text { reservoir } \\
\text { surface area, } \\
\text { in acres }\end{array}$ & $\begin{array}{c}\text { End-of-month } \\
\text { reservoir } \\
\text { storage, } \\
\text { in acre-feet }\end{array}$ \\
\hline Average annual minimum- & $\begin{array}{c}8,963 \\
8,846\end{array}$ & $\begin{array}{r}1,718 \\
366\end{array}$ & $\begin{array}{r}124,035 \\
4,845\end{array}$ \\
\hline
\end{tabular}

The annual maximum end-of-month drawdown below the elevation at full storage $(9,017 \mathrm{ft}$ with a reservoir storage of 254,036 acre- $\mathrm{ft})$ would have averaged $54 \mathrm{ft}$. The maximum end-of-month drawdown below the elevation at full storage would have been $171 \mathrm{ft}$. This would have occurred during April 1965, 1968, and 1969. It would have been necessary to reduce the diversion through Harold D. Roberts Tunnel to 10,700 acre-ft in April 1965, 6,300 acre-ft in April 1968, and 8,200 acre-ft in April 1969 in order to maintain the minimum end-of-month reservoir elevation at the invert of the tunnel $(8,846 \mathrm{ft})$.

Releases from Dillon Reservoir would have been $50 \mathrm{ft}^{3} / \mathrm{s}$ for 82 percent of the time. The minimum release from Dillon Reservoir would have been $42 \mathrm{ft}^{3} / \mathrm{s}$. The reservoir would have spilled 19 times during June, 27 times during July, and 5 times during August. Additional releases would have been required during 19 of the years to meet the decreed water requirements of Green Mountain Reservoir.

\section{DISSOLVED-SOLIDS CONCENTRATIONS IN THE COLORADO RIVER}

The mean-annual discharge-weighted dissolved-solids concentrations in the Colorado River at three sites for the 1942-77 water years are shown in figure 6. Prior to 1969 , daily water samples were composited into three or more samples per month for chemical analysis. This allowed for computation of annual weighted-average concentrations. Since 1969, average annual concentrations have been computed using a linear-regression analysis of daily records of specific conductance versus dissolved solids. The values noted as "Historic" in figure 6 represent concentrations computed for these sites under actual conditions (including actual diversions from Dillon Reservoir). The values noted as "With 131,000 acre-feet diversion" represent the concentrations computed for these sites if 131,000 acre-ft of water with a dissolved-solids concentration of $100 \mathrm{mg} / \mathrm{L}$ (milligrams per liter) had been diverted from the Blue River basin each year. During dry years, some portion of the diversions through the Harold $D$. Roberts Tunnel will come from water 


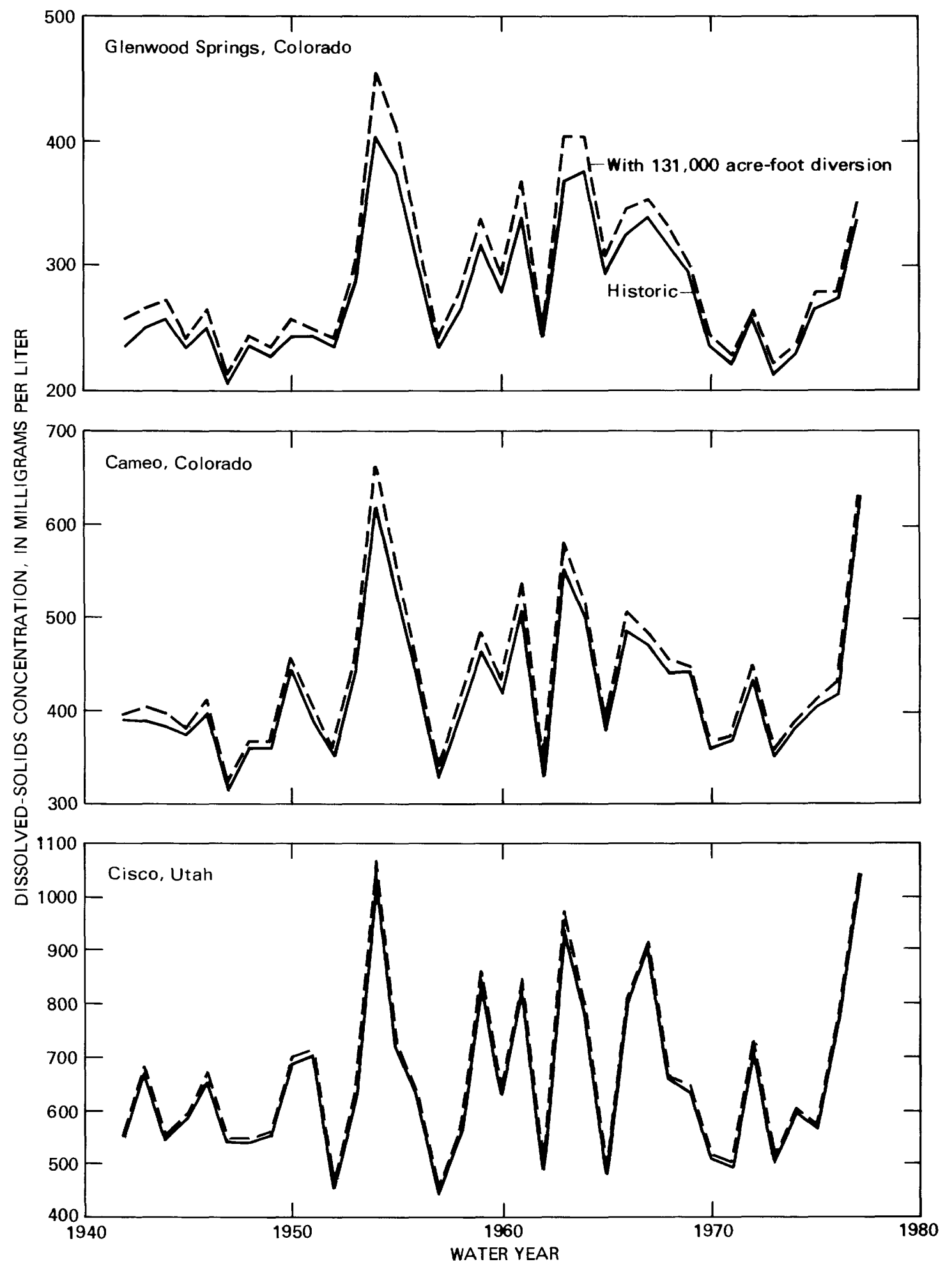

Figure 6.--Dissolved-solids concentrations (mean-annual discharge-weighted) at selected sites on the Colorado River (1942-77 water years). 
held in storage at Dillon Reservoir from previous wetter years. Therefore, during dry years, increases in dissolved-solids concentrations at the three Colorado River sites, as a result of a diversion of 131,000 acre-ft of water, may be less than those shown in figure 6 .

The average measured discharge-weighted, dissolved-solids concentration for the Colorado River for this 36-year period is $278 \mathrm{mg} / \mathrm{L}$ near Glenwood Springs, Colo.; $424 \mathrm{mg} / \mathrm{L}$ near Cameo, Colo.; and $653 \mathrm{mg} / \mathrm{L}$ near Cisco, Utah. The average increase of the dissolved-solids concentration for the 1942-77 water years, as a result of an annual diversion of 131,000 acre-ft, would have been $16 \mathrm{mg} / \mathrm{L}$ near Glenwood Springs, Colo.; $15 \mathrm{mg} / \mathrm{L}$ near Cameo, Colo.; and $15 \mathrm{mg} / \mathrm{L}$ near Cisco, Utah.

For comparative purposes, National Secondary Drinking Water Regulations established by the U.S. Environmental Protection Agency (1977) recommend $500 \mathrm{mg} / \mathrm{L}$ of dissolved solids for municipal supplies. Recommended guidelines for dissolved solids in irrigation water (U.S. Environmental Protection Agency, 1976) are shown in table 4.

Table 4.--Recommended guidelines for dissolved solids in irrigation water

[U.S. Environmental Protection Agency, 1976]

Classification

Dissolved solids, in milligrams per liter

Water from which no detrimental effects will

usually be noticed--

500

Water which can have detrimental effects on sensitive crops

$500-1,000$

Water that may have adverse effects on many crops

and requires careful management practices-----

$1,000-2,000$

Water that can be used for tolerant plants on permeable soils with careful management practices---

$2,000-5,000$

\section{SUMMARY}

Estimates of end-of-month storage in Dillon Reservoir, assuming the reservoir was in place and 131,000 acre-ft of water were diverted from the reservoir each year, were reconstructed by mass balance for the 1931-77 water years. The reconstructed data may be used to predict future effects of a similar annual diversion of 131,000 acre-ft of water, assuming that future hydrologic conditions will be similar to historic hydrologic conditions.

Based on the analysis, the annual maximum end-of-month drawdown below the elevation at full storage would have averaged $54 \mathrm{ft}$. The maximum end-ofmonth drawdown below the elevation at full storage would have been $171 \mathrm{ft}$. 
The mean-annual discharge-weighted dissolved-solids concentrations in the Colorado River near Glenwood Springs and Cameo, Colo., and Cisco, Utah, for the 1942-77 water years were computed for historic conditions and for conditions assuming an annual diversion of 131,000 acre-ft of water from Dillon Reservoir. The average increases in the dissolved-solids concentrations with the 131,000-acre-ft diversion were 15 to $16 \mathrm{mg} / \mathrm{L}$ at the three sites.

\section{REFERENCES}

Ficke, J. F., Adams, D. B., and Danielson, T. W., 1977, Evaporation from seven reservoirs in the Denver water supply system, central Colorado: U.S. Geological Survey Water-Resources Investigations 76-114, $170 \mathrm{p}$.

Harbeck, G. E., Jr., 1962, A practical field technique for measuring reservoir evaporation utilizing mass-transfer theory: U.S. Geological Survey Professional Paper 272-E, P. 101-105.

Knudsen, W. I., Jr., and Danielson, J.A., 1977, A discussion of legal and institutional constraints of energy-related water development in the Yampa River basin, northwestern Colorado: U.S. Geological Survey Contract Completion Report 14-08-0001-15075, December 1977, 20 p.

U.S. Department of the Interior, 1977, Final environmental statement, proposed Foothills project: Washington, D.C., v. 1 and 2.

U.S. Environmental Data Service, 1966-72, Climatological data, Colorado: Washington, D.C., U.S. Department of Commerce, annual summaries.

U.S. Environmental Protection Agency, 1976 [1977], Quality criteria for water: Washington, D.C., U.S. Government Printing office, 256 p.

1977, National secondary drinking water regulations: Federal Register, v. 42, no. 62, Thursday, March 31, 1977, Part 1, p. 17143-17147.

U.S. Geological Survey, 1954, Compilation of records of surface waters of the United States through September 1950--Part 9, Colorado River basin: J.S. Geological Survey Water-Supply Paper 1313, 749 p.

1964, Compilation of records of surface waters of the United States, October 1950 to September 1960--Part 9, Colorado River basin: U.S. Geological Survey Water-Supply Paper 1733, 586 p.

1961-74, Water resources data for Colorado--Part 1, Surface water records: Denver, annual reports.

1975-76, Water resources data for Colorado--Volume 2, Colorado River basin: Denver, Water-Data Reports C0-75-2 and C0-76-2.

1977, Water resources data for Colorado--Volume 2, Colorado River basin in Colorado, above the Dolores River: Denver, Water-Data Report c0-77-2.

U.S. Weather Bureau, 1930 and 1961-66, Climatological data, Colorado: Washington, D.C., annual summaries.

1954, Climatic summary of the United States, Supplement for 1931 through 1952, Colorado--Climatography of the United States: U.S. Weather Bureau Report 11-5, $62 \mathrm{p}$.

1964, Climatic summary of the United States, Supplement for 1951 through 1960, Colorado--Climatography of the United States: U.S. Weather Bureau Report 86-5, $86 \mathrm{p}$. 